\title{
Justice's Merger Guidelines: The General Theory
}

\author{
Phillip Areeda $†$
}

The antitrust laws forbid, in vague and general terms, unreasonable conspiratorial restraints of trade, inonopolization, and certain other practices that may tend substantially to lessen competition. ${ }^{1}$ Although the Federal Trade Commission and the Justice Departinent are two government agencies dedicated to the enforcenent of these statutes, the courts rather than these agencies have created the governing corpus of antitrust law inuch as the courts created tort and contract law.

Antitrust law is frequently unclear. In addition to the usual obscurities of judge-nade law, antitrust law is informed by economics, as perceived by lawyers and judges. Both the economists' views and the law's perceptions of those views change. Moreover, nany lawyers and judges have not had the opportunity to probe beneath the frequently opaque precedents and seein to apply the jargon of antitrust doctrime without considering its underlying rationale. Finally, the governing doctrimes frequently call for information that is not available and for conclusions that are not knowable. At best, antitrust law frequently deals in approximations, presumptions, and rules of thunib.

The resulting burdens on business and the courts have grown with the antitrust statutes' expanding coverage. Although they apply only to monopolization or restraints involving interstate commerce, the courts have broadly extended these several concepts. And government enforceinent is coupled with an explosion of private litigation as unhappy plaintiffs seek the consolation of treble damages and other businessinen use antitrust suits or counterclaims as strategic elennents in marketplace bargaining. ${ }^{2}$

The need for rationalization and clarification of the antitrust laws

$\dagger$ Langdell Professor of Law, Harvard University.

1. To avoid unseemly repeated references to my own writings, I refer here to 4 P. AREeDA \& D. TURNER, ANTITRUST LAW 117905 (role of arbitrary rules), 909-910 (relevance of market shares), 911d (condemnation of early mergers that do not themselves limit competition), 913 (strengths and weaknesses of the HHI), 916-922 (market factors other than seller shares), 923-938 (factors affecting the competitive significance of a particular firm, including analysis of General Dynamics and the failing company defense), 939-962 (ecouomies defense), 1003-1015 (economic consequences of vertical mergers) (1980); 5 id. I 1100-1152 (legal and economic analysis of conglomerate mergers).

2. An obvious illustration is a target management's boilerplate antitrust and securities claims for injunctive relief against an unfriendly takeover. 
is clear. More explicit legislation is theoretically possible, but not likely from a Congress that finds consensus difficult on more than meaningless generalities. In the main, Congress has altered the antitrust laws only "procedurally" simce 1914. Occasionally, a judicial opinion achieves new clarity. And beyond those formal sources of law are the commentators and the public enforcement agencies.

Guidelines indicating government enforcement intentions are one means of clarifying the law. Accordingly, the Justice Department promulgated Merger Guidelines in $1968^{3}$ and in $1982^{4}$ statimg how it intends to apply section 7 of the Clayton Act to inerger transactions. The articles in this Symposium analyze the impact and iniplications of the new 1982 Guidelines.

This Article outlines what I believe to be some of the major effects and potential problems surrounding the new Merger Guidelines. I discuss (1) the influence of enforcenent agency views and case selection on private conduct; (2) the effect of the new Guidelines on enforcement agency case selection and on judicial decisions; and (3) several of the probleins that may be encountered in the applying the new Guidelines. This Article then concludes that these Guidelines' main function, and a useful one, is to present the current administration's mode of merger analysis.

\section{I}

\section{The Role of Enforcement Agencies}

Enforcenent agencies affect the law and the citizenry both directly and indirectly. As a litigant or amicus, the Antitrust Division's views often, though certainly not always, receive considerable weight from the courts. As a collector of information about actual business behavior and economic performance, as a consistent analyst of legal economic antitrust issues, as keeper of the antitrust faith, and as the proponent of the public interest-or at least as thus idealized-the Justice Department's views command greater respect than those of ordinary litigants. In thus advising the courts, the government influences the content of antitrust law, its application in particular cases, and the resulting guidance to the business community.

The government's selection of problems and industries to investigate and cases to initiate may also influence private conduct. That influence varies, of course, according to the area of antitrust law that is being considered. It nay be minimal in those areas already attracting a

3. U.S. Dep't of Justice, Merger Guidelines-1968 (May 30, 1968), reprinted in 2 TRADE REg. REP. (CCH) I 4510 (Aug. 9, 1982).

4. U.S. Dep't of Justice, Merger Guidelines, 47 Fed. Reg. 28,493 (1982), reprinted in 71 Calif. L. Rev. 649 (1983). 
plenitude of private plaintiffs. In those areas, the threat of suit, the grist for the judicial mill, and the resulting array of legal doctrines will occur even though the Justice Departinent sues no one. In other antitrust areas, however, there may be few private plaintiffs. For exanple, apart froin the relatively few hostile takeovers, the inerging firms theinselves will not sue to enforce antitrust prohibitions. The persons most immediately affected-supphiers, employees, or dealers who become redundant after integration of the nierging firms-generally lack standing. ${ }^{5}$ Their injury has not resulted from reduced competition in the inerging firuns' inarket(s). Without such "antitrust injury," these would-be plaintiffs cannot sue under the antitrust laws. Those who would suffer froin reduced competition-for example, consuiners purchasing the product of former coinpetitors who inerged-would almost surely not suffer any provable damage from most illegal mergers. ${ }^{6}$ Most inerger condemnations reflect a prediction of possible future coinpetitive detriinents rather than any immediate impact on prices.

With relatively few private antitrust suits against inergers, businessinen could largely ignore section 7 of the Clayton Act if the governinent chooses not to challenge a inerger. Without government-imitiated hitigation, noreover, the courts would have relatively hittle occasion to develop any refined body of antimerger law in this area. Accordingly, Federal Trade Commission and Justice Departınent case selection bears far nore heavily on mergers than on those areas of antitrust law with active private enforceinent, such as resale price inaintenance.

Government case selection affects business behavior in at least two ways. It discourages those actions likely to trigger an immediate government suit. And, over the long run, it influences the kinds of probleins with which antitrust tribunals have to cope and thus the shape of the resulting precedents. Case selection also guides lawyers familiar with recent inergers that the government decided not to challenge. More widely available to the citizenry, of course, are published statements of government enforcement intentions.

\section{II}

\section{The Merger Guidelines' EFfect}

The Justice Departınent's Merger Guidelimes, both the 1968 and 1982 versions, state their enforceinent intentions. In addition, they state a policy rationale for applying section 7 of the Clayton Act and a inode of analysis-a guide to the thinking process of the Antitrust Division, or at least of its current chief, a nodel of questions to be consid-

5. See 2 P. AREeDA \& D. TuRner, supra note 1, If 339 (1978).

6. See id. โโ 335-337. 
ered or not considered, the sequence of the inquiry, and partial observations on possible solutions.

The promulgators of the Guidelines invariably say that such guidance is designed to reduce the uncertainty facing citizens and to give them an advance and reliable indication of where they are likely to stand with the present Justice Departınent. The Guidelines also have four additional targets: subordinates within the Antitrust Division, successor administrations, the Federal Trade Commission, and the courts.

Once published, and until changed, an official guideline limits the issuing agency's behavior. To be sure, the Guidelines contain escape clauses allowing the government to attack apparently safe inergers or to acquiesce in apparently challengeable mergers. But widespread departures are unlikely. Accordingly, the Guidelines serve as rather formal imstructions to the Antitrust Division staff on how to approach mergers. Such instructions to the staff will survive the current administration, and will tend to bind a future Attorney General until he is ready to disown them coinpletely or to undertake the significant burden of revising them. Given the power of inertia, the Guidelines are likely to last.

Although a Justice Departinent statement of its enforcement intentions does not formally restrict the Federal Trade Cominission's power, it tends to do so in two ways. First, the cominissioners surely recognize the unseemliness and apparent disarray of having two government agencies concurrently enforcing a single statute according to radically different criteria. To soine degree, therefore, the issuance of Justice Departinent Guidelines preempts FTC choices. And although the Commission's own public statement denies perfect accord with the Guidelines, ${ }^{7}$ great disparity is clearly not to be expected. To be sure, the Guidelines theinselves contain significant elasticity that permits the appraisal of some inergers to vary according to which agency takes jurisdiction. Second, the Commission's choices, of course, will be limited to the extent that the Guidelines find favor with the courts.

The Guidelines are not expressly addressed to the courts as, if you will, a standing amicus brief on section 7 theory and applications. ${ }^{8}$ The Department even denies that it is stating its litigation positions and ex-

7. See FTC, Statement Concerning Horizontal Mergers (June 14, 1982), reprinted in TRADE REG. ReP. (CCH) No. 546, at 71 (June 16, 1982) (special supplement to 2 TrADe ReG. REP. (CCH) If 4225 (Aug. 9, 1982)).

8. The courts are not bound by Justice Department Guidelines. United States v. Atlantic Richfield Co., 297 F. Supp. 1061, 1073 (S.D.N.Y. 1969), affd mem. sub nom. Bartlett v. United States, 401 U.S. 986 (1971). However, courts may give weight to an agency's statement of its enforcement imtentions as bearing upon the concept of reasonableness or substantiality. See AllisChalmers Mfg. Co. v. White Consol. Indus., 414 F.2d 506, 524 (3d Cir. 1969), cert. denied, 396 U.S. 1009 (1970). 
pressly reserves the privilege of asking the court to ignore factors declared relevant in the Guidelines. Indeed, one might wonder whether the drafters wish courts to bog down in the variety of factors, such as entry barriers and buyer concentration, that the prosecutors intend to consider. On the other hand, some of the Departinent's reasoning-for example, on rejecting an efficiencies defense-bears more on hitigation difficulties than on the exercise of prosecutorial discretion.

I base iny assessment of Justice Department intentions less on particular provisions of the Guidelines than on their general structure and the promulgators' general attitude. The drafters apparently hope to influence the courts. The drafters wrote the Guidelines in inuch more elaborate detail than would be required merely to guide the Department staff or the busmess community. For example, an intent to persuade the courts seems to be the only explanation for the rather complex, although sketchy, histing of infrequent competitive threats from vertical mergers. The drafters seem to be telling the courts that all other vertical mergers should be ignored. Furthermore, the Division's officials have given every indication of a mission to improve and rectify antitrust law, a mission pursued through public statement, amicus briefs, and the Guidelines.

\section{III \\ GENERAL OBSERVATIONS}

It is easy to find fault with any guidelines, including these. Guidelines never live up to the hopes or promises of their drafters. There is seldom analysis enough or time enough to create ideal guidelines. A detailed exammation and critique of the Guidelines is not my function in this Symposium, but a few general observations may be made with respect to several specific provisions.

First, although guidelines can reduce uncertaimty to some degree, certainty usually turns out to be an elusive hope. These Guidelines recognize that any antitrust test involving market shares can only be as good as the market definition and the available data. Accordingly, the Guidelines discuss at length the first problem facing the user of the Guidelines-the market definition im the context of horizontal mergers. They correctly relate market definition to the ultimate legal issue-the prospect that the inerging firms will achieve price-raising power or that the merger will facilitate price coordination among oligopolists. The potential influx of the product froin its producers in other regions or from producers of other products who can readily shift their output is critically important. The drafters measure this influx within six or twelve months of a hypothetical 5\% price rise for the merging firms' product. The drafters do not explain the relevance of such an incre- 
mental change in a price that is already monopolistic. Even with a competitive price, the precision of the $5 \%$ number and the six or twelve months is a bit curious. The specifications are entirely arbitrary, the consequences are necessarily speculative, and the relevant imflux magmitudes are unspecified. I do not suggest that the general approach is wrong, ${ }^{9}$ but only that the appearance of clear guidance is illusory. ${ }^{10}$

Second, data availability is another problem facing the user of any merger guidelines, a problem that is exacerbated by these Guidelines' use of the Herfindahl-Hirschman Index ("HHI"). ${ }^{11}$ That imdex has several important and perhaps critical virtues, but it requires more data than is customarily available. It also magnifies any errors in the data. The drafters surely recognized these problems and hoped to overcome thein by making their categories of safe, troublesome, and very troublesome mergers gross enough to swamp errors in the use of HerfindahlHirschman indices. Experience will test the seriousness of the data problem, and the drafters have expressed a willingness to respond to such experience.

The choice of the particular HHI threshold levels and the presumptively forbidden increments is, like several elements of the market definition section, entirely arbitrary. Indeed, some measure of arbitrarmess is inevitable when neither cconomic theory nor empirical studies answer the statutory question of when competition is "substantially lessened." However, one might have expected rather elaborate Guidelines to justify the arbitrary approach and to explaim the reasoning process behind the conclusion that mergers are tolerable im markets with HHI below 1000 and presumptively illegal if the merger mcreases an index above 1000 by 100 poimts or mcreases an mdex above 1800 by 50 poimts. ${ }^{12}$ To be sure, explaining an arbitrary choice is usually difficult,

9. An occasional specific point is erroneous. For example, it is said that the lack of power over price notwithstandimg a large inarket share ineans that the market has been defined too narrowly. It is not true, however, that everything relevant to inarket power can be expressed by the narket definition. Even the Guidelines themselves recognize this by considering potential entry as a suppleinentary matter. Furthermore, the demand curve for a given product may be too flat to allow exploitative power even to the sole producer of a product. To be sure, such a weak demand may reflect buyer preference for other products or services generally, but this cannot be captured by the market definition.

10. There are several additional sources of uncertainty. The Guidelines do not indicate how the Department will assess foreign competition in defining geographic markets. Nor do the Guidelines indicate when something less than a firm's whole capacity will be imcluded in the universe in which the merging firms' market share will be ineasured.

I1. The HHI is simply the sum of the squares of the market shares of the firms in a market. Because a percentage share less than 100 is expressed in decimal numbers, the HHI for any market not inhabited by a simgle firm with a $100 \%$ market share is less than 1 . For simphicity, but without explanation, the Guidelines' drafters dropped the decimal poimt and expressed the perfect monopoly not as 1 but as 10,000 . The HHI for a market inhabited by ten firins, each with $10 \%$, would thus be 1000 .

12. A merger always increases the $\mathrm{HHl}$, because the square of the combined shares of the 
and writers of official documents often hesitate to expose that which they cannot defend with very strong theoretical or empirical force. This hesitation is understandable even when the drafters chance to be humble because the document is, after all, a guideline and not a treatise.

Third, the Guidelines hist various factors relevant to the antitrust violation question but fail to indicate how to apply them. The particular HHI threshold numbers chosen do not purport to be determinative but are to be considered along with ease of entry, degree of product homogeneity, next closest products or producers excluded from the market definition, buyer concentration, information availability or exchanges, economic performance, prior disruptiveness of a inerging firm, and such practices as price protection clauses, product standardization, dehvered pricing, past collusion, and other matters affecting the ease of tacit price coordmation. At this point, unfortunately, the Guidelines become a hopelessly vague list of factors and threaten to lose most of their guidance value to businessmen and courts. ${ }^{13}$

Such factors are undemably relevant to the economic consequences of a merger. But there is no consistent or predictable way to measure or combine them. The Guidelines do not tell us how these factors are to be used, to what degree they will affect the legality of a merger, or how factors poimting in different directions are to be balanced. Perhaps the drafters meant to consider these factors only when they all point in the same direction, or only when they are clear enough on net balance to produce an unmistakable conclusion, or only as tie breakers for mergers just over or under a numerical threshold. But the drafters' vagueness on these poimts may lead to ad hoc administration, and even worse, invite litigants and judges to make merger cases unmanageably complex in litigation and greatly uncertain in result. The imtroduction of these factors without guidance as to their use creates a serious potential for judicial mischief.

It is also difficult to reconcile the drafters' receptiveness to those uncertain factors with their refusal, on grounds of excessive complexity, to consider a merger's procompetitive efficiencies. These efficiencies are also undeniably relevant in principle to the drafters' goal of economic efficiency. Similarly, the exceedingly sketchy treatment of the failing company defense is hard to explain. The defense is legislatively

merging firms necessarily exceeds the sum of the squares of their individual shares. For example, the combined HHI for two $5 \%$ firms before their merger is $(5 \times 5)+(5 \times 5)=50$. The merged firm's index is $10 \times 10=100$. The HHI index for this market rises by 50 points as a result of this merger.

13. This is not to say that the Division has departed from precedent. Some of the lower courts have chosen an expansive reading of Umited States v. General Dynamics Corp., 415 U.S. 486 (1974), to permit consideration of a wide variety of factors possibly bearing on competitive effects. See, e.g., Kaiser Aluminum \& Chem. Corp. v. FTC, 652 F.2d 1324 (7th Cir. 1981). 
recognized even though the present Division would prefer that it not exist. Given its existence, however, it deserves more complete treatment and analysis than provided by the Guidelines, although one can sympathize with the drafters' desire to publish their primary conclusion before taking time to deliberate on all the relevant concerns.

Fourth, a key horizontal merger issue that is only imferentially treated in the Guidelines is whether we should prevent a merger that does not itself impair competition but that would do so if replicated by similarly situated firms in that market. To be sure, principles of justice need not forbid condemnation of a later inerger of the same magmitude as an earlier inerger in that market. That the market concentration after the second merger exceeds that resulting from the first distimguishes the two transactions. But this very distimction can itself create an incentive to inerge earlier rather than later. Creatimg additional imcentives to merge is hardly the purpose of section 7 .

Finally, the Guidelines' treatınent of vertical mergers reflects an ambivalence of purpose. The Guidelines neither define in detail which vertical mergers will be challenged nor analyze very far the ways im which vertical mergers might reduce competition. The Guidelines mention several anticompetitive possibilities, but do not work through the preconditions for their existence. This section of the Guidelines seems to be a cross between a treatise and a guideline without being satisfactory as either. Of course, the Guidelines do indicate that the government will seldom attack a vertical merger. This might be sufficient guidance for businessinen though not for courts. Agam, the drafters did not have time to resolve all of the potential problems with the Guidelines.

\section{CONCLUSION}

Although superfluous, a general conclusion does emerge: these Guidelines are mainly useful as revealing the present administration's mode of analyzing mergers, especially horizontal mergers. The analytical road napped out is generally sound. The Guidelines are relatively concise and relatively accessible to businessmen, lawyers, and judges who are not already experts in antitrust law. Furthermore, the Guidelines will provide busmessinen reasonable guidance if market definition contmues to be shaped heavily by what data is available (rather than by pure economic principle) and if the HHI numbers specified by the Guidelines will usually govern enforcement actions except for the rare case in which the normuinerical factors are clear, important, and point in a single direction. The impact of the Guidelines on the courts, however, seems to be much more problematic. 